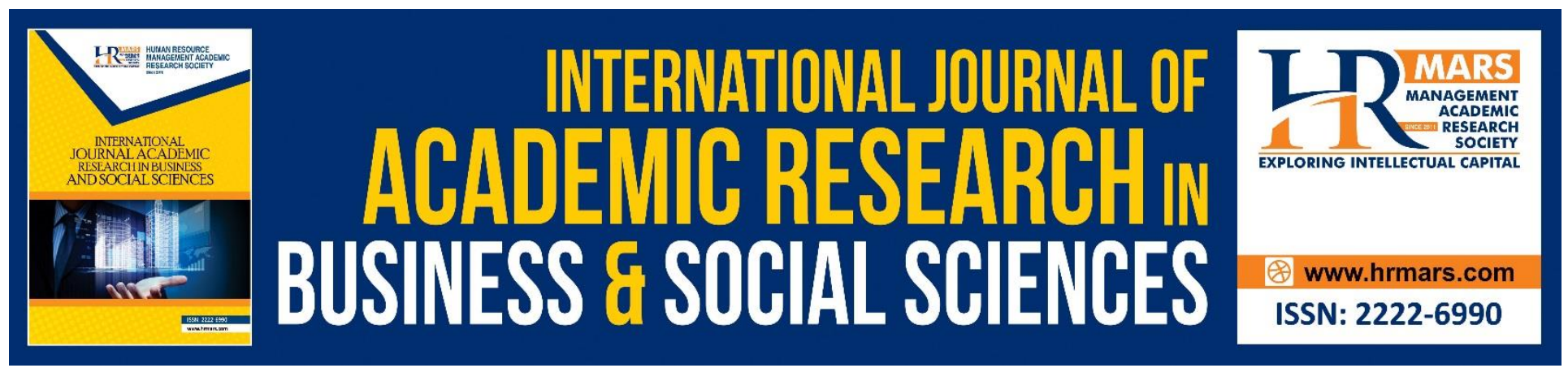

\title{
Issues in promoting Communicative Competence among Malaysian Primary School Students
}

Siti Hajjar Sheikh Mohd Fazil, Faizah Mohamad Nor, Nurul Alia Abdul Halim

To Link this Article: http://dx.doi.org/10.6007/IJARBSS/v8-i8/4617

DOI: $\quad 10.6007 /$ IJARBSS/v8-i8/4617

Received: 24 June 2018, Revised: 19 July 2018, Accepted: 29 July 2018

Published Online: 18 August 2018

In-Text Citation: (Fazil, Nor, \& Halim, 2018)

To Cite this Article: Fazil, S. H. S. M., Nor, F. M., \& Halim, N. A. A. (2018). Issues in promoting Communicative Competence among Malaysian Primary School Students. International Journal of Academic Research in Business and Social Sciences, 8(8), 608-619.

\section{Copyright: (C) 2018 The Author(s)}

Published by Human Resource Management Academic Research Society (www.hrmars.com)

This article is published under the Creative Commons Attribution (CC BY 4.0) license. Anyone may reproduce, distribute, translate and create derivative works of this article (for both commercial and non-commercial purposes), subject to full attribution to the original publication and authors. The full terms of this license may be seen at: $\underline{\text { http://creativecommons.org/licences/by/4.0/legalcode }}$

Vol. 8, No. 8, August 2018, Pg. 608 - 619

http://hrmars.com/index.php/pages/detail/IJARBSS

JOURNAL HOMEPAGE

Full Terms \& Conditions of access and use can be found at http://hrmars.com/index.php/pages/detail/publication-ethics 


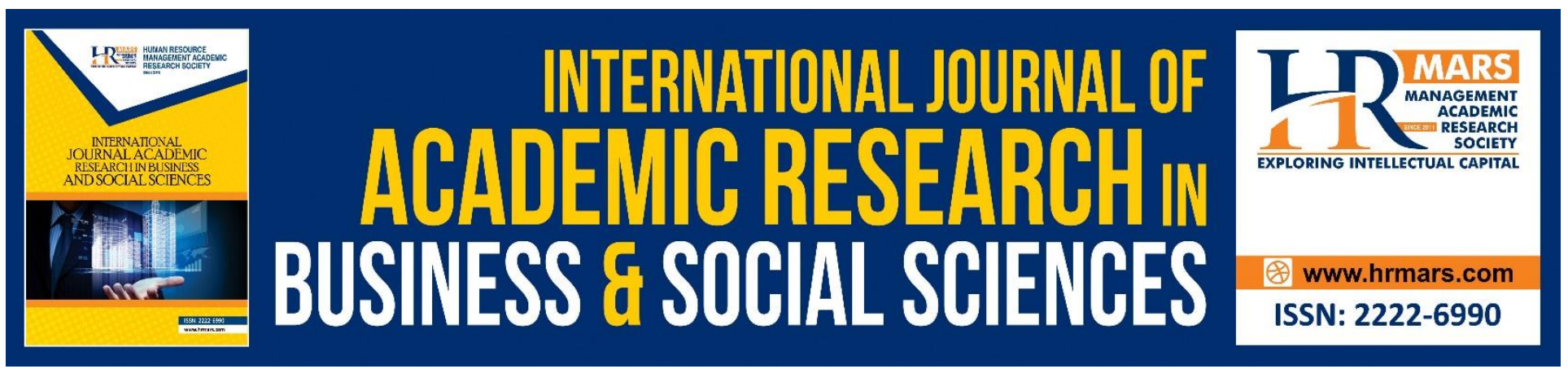

\title{
Issues in promoting Communicative Competence among Malaysian Primary School Students
}

\author{
Siti Hajjar Sheikh Mohd Fazil \\ School of Education, Universiti Teknologi Malaysia, Malaysia \\ Faizah Mohamad Nor \\ Language Academy, Universiti Teknologi Malaysia, Malaysia \\ Nurul Alia Abdul Halim \\ Faculty of Social Science and Humanities, Universiti Kebangsaan Malaysia, Malaysia
}

\begin{abstract}
This paper intends to examine and discuss the issues that the Malaysian English language primary school teachers faced in promoting Communicative Competence among their students when teaching speaking skill in the classroom. It aims to draw attention to the underlying reasons given by the teachers about the issues that they face in promoting Communicative Competence (CC) when teaching speaking skill in the classroom. This study implied a qualitative approach in which four English language teachers from one selected Sekolah Kebangsaan took part in the case study and the data were collected through classroom observation and interview. Later, the data had been analysed and coded under three main themes: (a) classroom management; (b) classroom teaching; and (c) student learning. The teachers lacked of understanding of the CC concept, their difficulty in managing big classes and their students who had no interest in learning English were among the issues that they had to face every day. However, teachers should not lose hope in improving the primary school students' communicative competence in speaking English. Teachers could adapt their teaching techniques and devise classroom activities that cater the students' level of proficiency in order to attract the students' interest in learning the target language.

Keywords: Communicative Competence, speaking skill, Malaysian primary school, Communicative Language Teaching, English language
\end{abstract}

\section{Introduction}

Communicative Competence (CC) concept was first proposed by Dell Hymes a sociolinguistic scholar in 1972. According to Hymes in order to communicate effectively in a language the speakers need to have more than just grammatical knowledge. Later, other CLT scholars namely Richards and Savignon elaborated this concept in length. It includes knowing how to use the language for different 
purposes and functions, knowing how to diverse the use of language so that it suits the settings and the participants, knowing how to create and comprehend different types of texts such as reports, narratives and conversations and knowing how to sustain communication despite the restriction in one's language knowledge. In order to achieve CC, an approach called Communicative Language Teaching (CLT) was developed in the 1970's. It was seen as an ultimate approach that would defy the weaknesses of the previous teaching approaches such as Grammar Translation method and Audio Lingual Method. The main focus of CLT is the engagement of learners in communication in order to allow them to improve their communicative competence (Richards, 2006; Savignon, 2007) in which the two methods mentioned earlier did not provide for the learners previously.

CLT was later then exported actively throughout the world as a complete package of ideas and techniques. Malaysia along with its Asian neighbouring countries also began to adapt CLT in its syllabus and curriculum. The implementation of CLT in Malaysian primary schools can be seen with the rise of the CLT in the mid 1970's (Mohd Asraf, 1996). The syllabus in the 1970's onward was based on the structural situational approach (Mustafa, 2009). It was the first common content syllabus that used a common content, method and teaching materials that led to a common examination (Darus, 2009). The transition to CLT syllabus was also the result of The Third Malaysian Plan 1976-1980 that recognized English as the language used most in international trade and commerce and also the main language in science and technology. There was a need for Malaysians to be fluent in English as an international language in order to achieve The Third Malaysian Plan aspiration (Foo \& Richards, 2004).

Since then the English language primary school curriculum had been reformed several times until the recent curriculum which was introduced in 2011 under the name Kurikulum Standard Sekolah Rendah (KSSR). This new curriculum is still designed around CLT and promotes CC among the primary school students. It aims to equip the students with basic language skills as to enable them to communicate effectively in a variety of contexts that are appropriate to the students' level of development. In addition, the objectives of the curriculum are to enable the students to: communicate with peers and adults confidently and appropriately in formal and informal situations; read and comprehend a range of English texts for information and enjoyment; write a range of texts using appropriate language, style and form using a variety of media; appreciate and demonstrate understanding of English language literary or creative works for enjoyment; and use correct and appropriate rules of grammar in speech and writing (Dokumen Standard, p. 5, 2015). The aims and objectives of KSSR clearly stated that the students need to achieve the communicative competence elements namely the sociocultural (communicate with peers and adults confidently and appropriately in formal and informal situations), strategic (students able to communicate effectively in a variety of contexts that are appropriate to their level of development), discourse (read and comprehend a range of English texts for information and enjoyment; write a range of texts using appropriate language, style and form using a variety of media; appreciate and demonstrate understanding of English language literary or creative works for enjoyment) and grammar (use correct and appropriate rules of grammar in speech and writing).

Since the implementation of KSSR numerous studies had been conducted related to it. These included on the teachers' perception on the new syllabus (Hardman \& A-Rahman, 2014; Munusamy, 2015), a review of the syllabus (Sulaiman, T., Ayub, A. F. M., \& Sulaiman, 2015), a study on the 
INTERNATIONAL JOURNAL OF ACADEMIC RESEARCH IN BUSINESS AND SOCIAL SCIENCES

Vol. 8, No. 8, August 2018, E-ISSN: 2222-6990 @ 2018 HRMARS

indigenous primary school students in KSSR classroom (Mihat, 2015) and using games in KSSR classrooms (Stapa, 2015). As KSSR is in its seventh year of implementation, little investigation was carried out on the issues that the teachers faced in promoting CC in the teaching of speaking skill in the classroom. Hence, this study aims to uncover some of the issues that emerged in the classroom and added more knowledge to the related field of the study.

\section{Review of the Literature}

In Malaysian education system, students from age seven to twelve years old attend primary schools. ). Since 1983 all the primary schools use KBSR syllabus (this syllabus is later revised in 2003) and the students are divided into two phases. Phase 1 comprises of Standards 1 to 3 and Phase 11, Standards 4 to 6 . In Phase 1, emphasises is given on the basic communication skills, reading, writing and arithmetic. They are taught to listen, say aloud, recognize and form symbols, numbers and the alphabets and to use all these in writing. They also have to learn basic counting and mathematical skills of addition, subtraction, division and multiplication. In Phase 11, students need to strengthen and build upon the basic skills that they learn in Phase 1. More emphasis is given on thinking and communication, especially logical reasoning and understand social and current issues. Both phases demand an implicit creation of opportunities for individual expressions such as through art, music and writing. Students' facilitation of understanding and employment of a variety of means to obtain knowledge are also key prominence in both phases (Sargunan, 1990). Thus, the ministry had decided to launch their new policy MBMMBI (Mempertabatkan Bahasa Malaysia Memperkasakan Bahasa Inggeris) which is translated to 'to uphold Bahasa Malaysia and to upgrade the English language' in 2010. With this new policy, the Standard 1 students who began their schooling year in January 2011 started to use KSSR (Kurikulum Standard Sekolah Rendah). The English language syllabus of KSSR is still based on CLT but with more improvement from the previous KBSR syllabus. Students now are divided into two stages, Stage One; Year 1 to Year 3 students and Stage Two; Year 4 to Year 6 students. This new syllabus is underpinned by six principles namely back to basics; learn is fun, meaningful and purposeful; focus on the learner; integrate salient new technologies; assessment for learning and character-building infused (Kurikulum, 2012). In addition to the learning of four language skills (listening, speaking, reading and writing) the ministry has also added language arts and grammar module into the syllabus. However, grammar module will only be introduced in Year 3 until Year 6. Along with the introduction of KSSR, the ministry also introduced Pentaksiran Berasaskan Sekolah (PBS) which is translated to School Based Assessment. This is to give opportunity for teachers to assess their students based on their level of competency. The introduction of PBS is an action to take away the exam-oriented system that has been carried out for decades in Malaysian education system. This is also aligned with the aim of the syllabus which is 'to equip pupils with basic skills to enable them to communicate effectively in a variety of context that is appropriate to the pupils' level of development' (Kurikulum Year 3, 2012. p. 1).

Along with the changes of curriculum and syllabus throughout the years, many researchers had carried out studies on communicative competence and the implementation of CLT in the Malaysian primary classroom. Wan (1990) in his study suggested that teaching drama in English through CLT provides opportunity for them to practice using the language that resembles a real life situation. Drama teaches students to stimulate authentic conversations, practice their fluency and accuracy, increase students' motivation and prepare them for real life situation and unpredictability in daily communication. He claimed that combining drama and CLT is an innovative method in 
INTERNATIONAL JOURNAL OF ACADEMIC RESEARCH IN BUSINESS AND SOCIAL SCIENCES

Vol. 8, No. 8, August 2018, E-ISSN: 2222-6990 @ 2018 HRMARS

learning language that provides a meaningful way in the process of learning English. Nevertheless, teachers should not treat them in isolation; they need to be integrated with other approaches and methods in assisting them to create better teaching and learning process.

In another study done by Hawanum Hussien (2004) a combination of CLT and using simple poems to teach grammar had some significant improvement in the students' achievement in class. Students also show improvement in their writing tasks. For those with average proficiency they seemed to know their mistakes whenever the teachers were pointing out the mistakes. However, they still made the same grammatical mistakes in their writing. Hawanum felt that it was due to the lack of accuracy concern, indirect effect of the CLT. Although this approach may have some drawbacks, it is a success to be able to break out from dull and boring grammar classes.

Siaw (2005) revealed in his study of the Malaysian and Taiwanese selected textbooks for schools, the implementation of CLT had little influence on the teaching of grammar. He suggested that a number of communicative tasks were needed to supplement the structural activities in the textbooks. He later added that implementing communicative tasks and activities will only be effective if the teachers were ready to integrate CLT principles into their lessons in the classroom.

Wan (1990) and Hussein (2004) studies on CLT activities show that teachers can incorporate CLT activities in Malaysian classrooms and the activities suit to cater our students' proficiency level although commonly teachers seem to focus more on reading and writing skills as our education system that is exam-oriented. Hence, teachers need to take a few steps to adopt and adapt these activities to cater to their students' needs and interest. This study intends to investigate if the primary school teachers adopt and adapt CLT activities in their lessons and if they do, how they do it. Siaw's (2005) findings indicated that CLT is only being effective if the teachers are ready to incorporate CLT in their lessons. This proves that teachers' attitude and beliefs are crucial in determine whether they want to implement CLT in their lessons. This study hopes to find out if the teachers have positive mind-set about CLT and if they are prepared to carry out the CLT principles in the classrooms.

In promoting CC among the students, teachers play a crucial role in planning and carrying out CLT in the classrooms. However, numerous studies on the teachers' understanding about CLT indicated that most teachers did not have enough knowledge about CLT. Teachers could not identify the CLT principles and its communicative activities (Chowdry, 2012). They had misconceptions about CLT hence hindered them from implementing CLT in the classrooms (Bataineh, Bataineh, \& Thabet, 2011; Liao, 2003; Weerawong, 2004; Wong, 2010). The teachers believed that CLT did not promote the teaching of grammar explicitly, it focused only on the teaching of speaking skills and it did not support the public examination that emphasised on testing the students' reading and writing skill.

Moreover, the teachers had difficulties to apply CLT activities such as role-play, games and pair work due to the classroom constraints and the students' attitudes. These include the classroom sizes that made it difficult for the teachers to control the class (Coskun, 2011; Kavanagh, 2012), students reluctant to accept the student-centred approach as they were accustomed to be passive learners who just absorbed whatever their teachers taught them (Kucuk, 2011; Yan, 2014) and the students felt that they will not use English in their daily life or future hence they had less motivation to learn English (Chen, 2003). In addition, the teachers opted to use more L1 in their teaching practice 
due to the students' low proficiency level in English. The teachers themselves had limited experience of conversing in English hence they did not have confidence to conduct their lessons fully in English (Butler, 2007).

In investigating on the teachers' opinion and attitudes towards CLT, Al Nouh (2008) found that the teachers' beliefs were found to be consistent with their teacher-centred practice. The teachers expressed a belief in error correction and in teaching grammar explicitly. In another study, Daandel's (2014) study about teachers' beliefs towards CLT in elementary school level in Salatiga, Indonesia indicated that the teachers believed that CLT activities such as games, role-play and information gap activity did promote the students to speak in English as they interacted with their teachers and friends in the target language. He also stated that teachers must have good classroom management and control in order to implement CLT in the classroom.

A. Rahman (2014) reported that the English teachers at the primary school in Malaysia attitudes and beliefs were more concerned with how much input they should be transmitted to the students and the different types of activities they needed to carry out in a lesson. The teachers believed that they just performed the roles of knowledge transmitter and evaluator. Thus, the classroom interactions in the classroom activities were dominated by teacher talk that focused on rote-learning, recitation and repetition of memorized information.

Nikian (2015) who studied on the pre-service teachers' attitudes and beliefs towards CLT in Malaysia revealed that the majority of the teachers had positive attitudes towards CLT while a few of them seemed did not understand and agreed only with some features of CLT. Some were agreed with the advantages of traditional methods such as Audio Lingual Method (ALM) and Grammar Translation Method (GTM) that emphasize the deductive grammar teaching and considered teachers played the important role in the classroom.

In another study Nishino (2009) who investigated the teachers' attitude and beliefs towards CLT in Japanese high schools stated that although the teachers held positive beliefs about CLT, their beliefs did not influence them to use it. Their beliefs were related to the school's environment and setting. In addition, the teachers' beliefs and attitudes also rooted from their students' feedbacks in the classrooms.

\section{Method}

This case study was based on four English language primary school teachers who taught speaking skill in the Year 3, 4, and 5 students in the Malaysian primary school classroom. The teachers were chosen based on several criteria. They were qualified and trained teachers under the Ministry of Education who must have at least 5 years teaching experience in English and went for the KSSR courses. Each teacher was asked to teach of an hour lesson and they were observed according to the criteria stipulated in the observation sheet. Later, the teachers were interviewed with a list of semistructured questions. Each teacher had undergone two observations and two interview sessions. 
INTERNATIONAL JOURNAL OF ACADEMIC RESEARCH IN BUSINESS AND SOCIAL SCIENCES

Vol. 8, No. 8, August 2018, E-ISSN: 2222-6990 @ 2018 HRMARS

\section{Results and Discussion}

The data derived from the study was analysed via Atlas.ti software version 7 and three main themes were identified under ten issues. They are listed in Table 1.

Table 1. Derived issues from the data collected

\begin{tabular}{ll}
\hline Emerging themes & Issues derived \\
\hline Classroom teaching & a) Use other methods other than CLT such as \\
& Grammar Translation Method \\
\hline b) Do not fully understand the concept of CC \\
and CLT
\end{tabular}

\section{Classroom Teaching}

Data derived from the observation shows that the teachers mostly used teacher-centred approach. They dominated the class and used drilling as a part of their methods in introducing new vocabulary. Through the interview session the teacher insisted to use the teacher-centred approach as one of the teacher indicated that she thought that student-centred cannot be used widely in the classroom because students were too weak and they depend on teacher to give them ideas to help them to read. Most of the time during the observation most of the teachers used Bahasa Melayu instead of English in the teaching and learning process. The teachers' reason of such action was that they believed their students did not understand the classroom instruction in English. Some teachers would speak in English and later translated the instructions in Bahasa Melayu. 
The teachers also admitted that they had not attended any courses on CLT and the schools did not send them to any courses or workshops that related in constructing communicative activities. They did not have the skill and knowledge in constructing and conducting communicative activities. During the observation, teachers used text book and activity book provided by the ministry as their teaching aids. They indicated that they followed the KKSR syllabus as their teaching guidance and mostly used the materials provided by the ministry. Lastly, the teachers did not clearly understand the concept of Communicative Competence and Communicative Language Teaching. Some even misunderstand the concept of CLT by indicating that CLT is not a method but a skill in teaching English language.

\section{Classroom Management}

Teachers chose to conduct communicative activities with high level students compared with low level students. Their reason was low level students depend more on the teachers. Thus, they could not carry out communicative activities on their own. Whereas, teachers preferred conducting communicative activities with high level students because they had better understanding of the task given and they could carry out the task on their own and they would act as the facilitators. Through classroom observation, low level students need constant help from the teachers as at time they did not understand the task given. One of the teachers indicated she preferred teacher-centred approach compared to student-centred when dealing with low level students as she believed low level students did not get any benefit from communicative activities due to their limited vocabulary in English language.

\section{Students Learning}

Most of the students pay attention to the teachers in the teaching and learning process based on the observation indicating that they were well-behaved students. Those who did not understand would ask the teachers in Malay and the teachers would respond in Malay. Teachers tend to translate instructions in Malay when they did not have positive respond with the students such as when the students did not understand what should they did in certain tasks or activities. Some students did understand the teachers' questions but they gave their responses in Malay and teachers would pronounce the words in English and asked the students to pronounce the words again in English.

The students also enjoyed doing role-play and group work activities. They were excited to come to the front of the class and did their presentation. They enjoyed acting up and reading dialogues. Even though most of the students used Malay as their main language they enjoyed the teaching and learning process. These elements of excitement and joy in learning English occurred among with the high level students. For the low level students they were inactive and just followed the teachers' instructions. They had no interest in learning English as some of them looked bored or confused.

The teachers believed that the students did not have any exposure in English at home and they solely rely on the teaching and learning in the classroom. They added that if the student had more opportunity to use English at home they would enjoy learning English at school. One of the teachers also indicated that the students were lazy to use the dictionary in finding new or difficult words that they learned in the classroom. They rely on teachers to spoon fed them with meanings 
INTERNATIONAL JOURNAL OF ACADEMIC RESEARCH IN BUSINESS AND SOCIAL SCIENCES

Vol. 8, No. 8, August 2018, E-ISSN: 2222-6990 @ 2018 HRMARS

and translate to them the words whenever they occur hence making the teaching and learning process became dull and boring.

\section{Implications and Recommendations}

Teachers tend to treat their students differently due to the students' level of proficiency in the target language. They believed that CLT can be carried out only with the good students as these students will use more English during classroom activities compared to the weak students. Teachers see no benefit of carrying out CLT activities as they feel their students would not learn anything from doing such activities. Such attitudes and beliefs could be the result of the Malaysian primary school education system that emphasis more on testing reading and writing skill compared on testing listening and speaking skill. Hence, teachers focus more on teaching their students vocabulary, grammar and writing simple essay. Teachers should not have double standard in the classroom when dealing with the students' level of proficiency. Every student deserves the same treatment regardless of their levels. Simplify and adapt the CLT activities to cater the students' proficiency. Train the low level students to use English in simple classroom instructions such as asking for permission to borrow things from friends or if they want to go out to the toilets. Take some efforts to write the most used classroom instructions and paste them in front of the class and encourage the students to use them all of the time. Give rewards to those who use the classroom instruction the most. Teachers have to provide opportunity for the students to speak and use English as much as possible.

The teachers' lack of understanding on the concept of CC and CLT also hinder them from applying CLT in the classroom. They seem to associate the concept that all the students must speak in the target language and no mother tongue is allowed in the classrooms. Whereas, if they clearly understand the concept of CLT they will know that students' native language is still permitted in CLT. However, teachers should emphasize the students to use the target language during the activities (Larsen-Freeman, 2006). In order to provide input for the teachers on the concept of CC and CLT, teachers should have a team of experienced teachers that will guide new teachers to construct their own CLT activities so they do not just rely on the materials that are provided from the ministry. School administrators and English language panel could utilize the Professional Learning Community (PLC) activities such as Lesson Study in guiding inexperienced teachers.

While the ministry do support teachers to be innovative and creative, most teachers choose to stick to activities or approaches that they believed will make the student pass the English exam paper rather than focusing on the students' ability to speak English fluently and accurately. Thus, they tend to use teacher-centred approach that they believe will bring results rather than student-centred activities that seem pointless especially to low level students. This issue will not be resolved until the ministry put more emphasis on testing listening and speaking skill in primary school public examination.

There is no doubt that the students enjoy role-play, pair and group works activities in the classroom. However, when the students get so excited class control can be an issue for the teachers. In a normal Malaysian classroom situation there must be at least 25 to 40 students in a classroom. Hence, teachers need to be wise to devise communicative activities that involve all the students and at the same time they do not lose control of the classroom. Try to limit the communicative activities to one activity per lesson. The students can sit to do group work for one particular activity and the 
INTERNATIONAL JOURNAL OF ACADEMIC RESEARCH IN BUSINESS AND SOCIAL SCIENCES

Vol. 8, No. 8, August 2018, E-ISSN: 2222-6990 @ 2018 HRMARS

rest of the lesson they can focus on individual work. Teachers can carry out many pair works activities so the students will have more chances to use the language among their peers.

In order to attract the students' interest in learning English, teachers should have an open mind and positive attitude. Give rewards to every student' achievement even if it is small. Give encouragement and praise them occasionally. Teaches should tolerate in correcting the students' errors as the learners are building up their communicative competence (Richards, 2006). The students might be intimidated to learn the target language if they are constantly being corrected by the teachers. Students need to have confident to speak language other than their mother tongue. Hence, teachers should always motivate their students to speak English all the time in and outside the classroom.

\section{Conclusion}

Issues that the teachers faced in promoting CC in teaching speaking skills can only be resolved if some contributing factors can be minimized or eliminated. However, some factors are not under the teachers' control namely the class size, students' low proficiency level and the Malaysian primary school public examination that emphasizes more on reading and writing skills. Teachers are constantly under dilemma and pressure whether to follow the KSSR syllabus or the administrators at the school, district and state level who want to see more students pass in the English language subject rather than focusing on improving the students' ability to speak English accurately and fluently.

Nevertheless, teachers should try to give their students more opportunity to use English and keep on promoting them to learn and build interest in mastering the language. Teachers could not possibly ensure that all their students would end their primary school as excellent students in English. Nevertheless, the teachers could provide their students with enough basic knowledge of the language that could help the students to learn more input about the language once they start their learning at the secondary level.

\section{Acknowledgement}

The authors are grateful to the Ministry of Higher Education for the Research Grant awarded to fund the FRGS research project entitled

"The FEXMELT (Framework for Excellence among Malaysian English Language Teachers: An Instrument for Selection of Excellent Local ELT Trainers in Malaysia)".

\section{Corresponding Author}

Siti Hajjar binti Sheikh Mohd Fazil. Universiti Teknologi Malaysia. Malaysia.

Email: ishaja99@yahoo.com

\section{References}

A. Rahman, N. H. (2014). From curriculum reform to classroom practice: an evaluation of the English primary curriculum in Malaysia. University of York.

Al Nouh, N. A. . (2008). Are Kuwaiti primary ESL teachers implementing a CLT-based learner-centred method in their classroom? Newcastle University. Retrieved from http://hdl.handle.net/10443/613 
INTERNATIONAL JOURNAL OF ACADEMIC RESEARCH IN BUSINESS AND SOCIAL SCIENCES

Vol. 8, No. 8, August 2018, E-ISSN: 2222-6990 @ 2018 HRMARS

Bataineh, R. F., Bataineh, R. F., \& Thabet, S. S. (2011). Communicative Language Teaching in the Yemeni EFL Classroom: Embraced or Merely Lip-serviced? Journal of Language Teaching and Research. http://doi.org/10.4304/jltr.2.4.859-866

Butler, Y. (2007). How Are Nonnative English Speaking Teachers Perceived by Young Learners? Tesol Quarterly. Retrieved

from /citations?view_op=view_citation\&continue=/scholar\%3Fhl\%3Den\%26start\%3D40\%26as_sdt\% 3D0,5\%26scilib\%3D1\&citilm=1\&citation_for_view=yvuL_clAAAAJ:YOwf2qJgpHMC\&hl=en\&oi=p

Chen, Z. (2003). The Difficulties of using CLT in China. Retrieved from http://www.math.mun.ca/

Chowdry, M. K. (2012). CLT Approach at higher secondary level in Bangladesh-Teachers' perceptions and classroom practice. Language In India, 12. Retrieved from www.languageinindia.com

Coskun, A. (2011). Investigation of the Application of Communicative Language Teaching in the English Language Classrooms - A Case Study on Teachers' Attitude in Turkey. Journal of Lingustics and Language Teaching, 2(1).

Daandel, P. (2014). Teachers' Perception in Applying Communicative Language Teaching in Elementary School Level. Retrieved from http://repository.uksw.edu/handle/123456789/5437

Darus, S. (2009). The Current Situation and Issues of the Teaching of English in Malaysia. Retrieved from www.ritsumei.ac.jp

Dokumen Standard, K. (2015). KSSR Dokumen Standard Kurikulum dan Pentaksiran Bahasa Inggeris Tahun Enam. Kementerian Pendidikan Malaysia.

Foo, B., \& Richards, C. (2004). English in Malaysia. RELC Journal. http://doi.org/10.1177/003368820403500209

Hardman, J., \& A-Rahman, N. (2014). Teachers and the implementation of a new English curriculum in Malaysia. Language, Culture and Curriculum, 27(3), 260-277. http://doi.org/10.1080/07908318.2014.980826

Kavanagh, B. (2012). The theory and practice of communicative language teaching in Japan. Academic Research International, 2(2), 730-738. Retrieved from http://www.savap.org.pk/journals/ARInt./Vol.2(2)/2012(2.2-80).pdf

Kucuk, A. N. (2011). The Application of Communicative Language Teaching (CLT) in Turkish Primary and Secondary Schools. Retrieved from http://www.httmag.co.uk/dec11/sart05.htm

Larsen-Freeman, D. (2006). Techniques and Principles in Language Teaching (2nd ed.). Oxford University Press.

Liao, X. (2003). Chinese secondary school EFL teachers' attitude towards communicative language teaching and their classroom practices. University of Auckland.

Mihat, W. (2015). The English Language Curriculum in Malaysian Indigenous Primary Classrooms: The Reality and the Ideal. 3L: Language, Linguistics, Literature ${ }^{\circledR}$. 3L: Language, Linguistics, Literature ${ }^{\circledR}, 21(3)$.

Mohd Asraf, R. (1996). The English Language Syllabus for the year 2000 and beyond-Lessons from the view of teachers. The English Teacher, XXV. Retrieved from www.melta.org

Munusamy, I. M. (2015). Teacher's Belief of the new Standard Curriculum for Primary Schools (KSSR) in Teaching English as (ESL) in Malaysian Schools: A Qualitative approach. Asian Journal of Multidisciplinary Studies, 3(5).

Mustafa, Z. (2009). ESL or EFL? TESL or TEFL? Retrieved from eprints.usm.my/9995/Nina_1.pdf

Nikian, S. (2015). Malaysian pre-service teachers attitudes towards the implementation of Communicative Language Teaching. Universiti Teknologi Malaysia.

Nishino, T. (2009). Communicative Language Teaching in Japanese High Schools: Teachers' Beliefs 
INTERNATIONAL JOURNAL OF ACADEMIC RESEARCH IN BUSINESS AND SOCIAL SCIENCES

Vol. 8, No. 8, August 2018, E-ISSN: 2222-6990 @ 2018 HRMARS

and Classroom Practices. Temple University.

Richards, J. C. (2006). Communicative Language Teaching Today. Language Teaching (25). http://doi.org/10.2307/3587463

Savignon, S. J. (2007). Beyond communicative language teaching: What's ahead? Journal of Pragmatics, 39(1), 207-220. http://doi.org/10.1016/j.pragma.2006.09.004

Stapa, S. H. (2015). Young Learners' Perceptions of Learning English Using Language Games in a NonFormal Context. EUROPEAN CENTER FOR SCIENCE EDUCATION AND RESEARCH, 11, 104.

Sulaiman, T., Ayub, A. F. M., \& Sulaiman, S. (2015). Curriculum Change in English Language Curriculum Advocates Higher Order Thinking Skills and Standard-Based Assessmenst in Malaysian Primary Schools. Mediterranean Journal of Social Sciences, 6(2), 494., 6(2), 494. http://doi.org/10.5901/mjss.2015.v6n2p494

Weerawong, A. (2004). COMMUNICATIVE LANGUAGE TEACHING IN PRACTICE ?: A STUDY OF FOUR POST-GRADUATE STUDENT TEACHERS IN THAILAND. National University of Singapore.

Wong, C.-Y. (Cathy). (2010). Second Language Teachers' Perception and Implementation of Communicative Language Teaching. Texas Tech University.

Yan, C. (2014). "We can"t change much unless the exams change': Teachers' dilemmas in the curriculum reform in China. Improving Schools, 18(1), 5-19. http://doi.org/10.1177/1365480214553744 